\title{
PENGETAHUAN REMAJA PUTRI TENTANG KEHAMILAN,DI WILAYAH KERJA PUSKESMAS KLUNGKUNG I, BALI TAHUN 2014
}

\author{
Ellen Kwesley \\ Program Studi Pendidikan Dokter Fakultas Kedokteran Universitas Udayana, Bali, Indonesia
} elstronout@hotmail.com

\begin{abstract}
ABSTRAK
Meningkatnya insiden kehamilan pada remaja putri dari tahun ke tahun akan memberikan pengaruh sosial dan kesehatan bagi remaja sendiri. Sejak 2010, angka kunjungan ibu hamil usia <20tahun di Puskesmas Klungkung I terus mengalami peningkatan.Penelitian ini untuk mengetahui bagaimana pengetahuan remaja putri mengenai kehamilan dini di wilayah kerja Puskesmas Klungkung I. Penelitian menggunakan rancangan penelitian deskriptif kualitatif. Sampel dipilih secara purposive. Data dikumpulkan dengan in-depth interview. Analisis data dengan metode analisis tematik. Penelitian dilaksanakan di Puskesmas Klungkung I pada tanggal 7 Agustus - 6 September 2014.Sebanyak 6 orang respondenterlibat dalam penelitian dengan karakteristik 1 orang tamat SD, 3 orang tamat SMP, dan 2 orang mengenyam pendidikan setingkat SMA, 1 orang belum menikah dan 3 responden sudah menikah saat hamil. Hasil penelitian menunjukkan pengetahuan remaja putri mengenai kehamilan dini mempengaruhi perilaku seksual pranikah.Pengetahuan responden mengenai kehamilan dini masih terbilang kurang sehingga responden tidak mengetahui dampak kehamilan dini dan tidak tahu mengenai pencegahan kehamilan. Sehingga diperlukan promosi kesehatan reproduksi yang lebih gencar, sehingga remaja bisa mendapatkan informasi yang benar dan akurat.
\end{abstract}

Kata kunci: remaja, kehamilan usia dini,pengetahuan

\section{ADOLESCENT KNOWLEDGE OF PREGNANCY IN KLUNGKUNG I PRIMARY HEALTH CARE COVERAGE, BALI 2014.}

\section{ABSTRACT}

The increasing incidence of pregnancies in young girls from year to year will cause health and social issues for teenagers themselves. Since 2010, the number of visits of pregnant women aged $<20$ years old in Puskesmas Klungkung I constantly increasing. This study purposes to know the knowledge of the young women about early pregnancy in Klungkung I Primary Health Care. Study used a qualitative descriptive research design. Samples were selected purposively. Data were collected by in-depth interviews. Analysis of data using thematic analysis method. Research conducted at Klungkung I Primary Health Care on August 7 to September 6, 2014. Total of 6 respondents engaged in research with the characteristics of education are diverse, 1 respondentis still unmarried and 3 respondents are married while pregnant. The results showed knowledge of the young women about pregnancy affect sexual behavior before marriage. Knowledge of respondents about pregnancy is still somewhat less so the respondents did not know the impact of early pregnancy and did not know about the prevention of pregnancy. So the promotion of reproductive health should be more intense, so that teens can get accurate information.

Keywords: adolescent, teen pregnancy, knowledge 


\section{PENDAHULUAN}

Masa remaja atau adolesens adalah sebuah periode transisi dari suatu masa kanak-kanak ke masa dewasa yang ditunjukkan dengan perubahanfisik, mental, emosional, maupun sosial yang mulai berkembang. WHOmendefinisikan remaja sebagai individu berusia 10-19 tahun, sedangkanmenurut UU No.4/1979 tentang kesejahteraan anak, remaja adalah individu $<21$ tahun dan belum menikah. ${ }^{1}$ Tahun 2010,Indonesia adalah negara peringkat ketiga yang memiliki remaja putri berusia 10-17 tahun terbanyak diantara negara lainnya atau berkisar $17,4 \%$ dari total seluruh kelompok usia remaja seluruh dunia. ${ }^{2}$ Indonesia menempati peringkat kelima dalam jumlah wanita berusia 20-24 tahun yang telah melahirkan pada usia 18 tahun pada tahun 2010. Dari data Riskesdas 2013, 2,68\% proporsi kehamilan wanita rentang usia 10-54 tahun dengan $0,02 \%$ umur $<15$ tahun dan $1,97 \%$ pada umur $10-19$ tahun. ${ }^{3,4}$

Dalam beberapa tahun terakhir terlihat kecenderungan peningkatan angka kunjungan remaja hamil di Puskesmas Klungkung I. Tahun 2010, kunjungan remaja hamil umur $<20$ tahun adalah 22 orang(3.9\%), 2011 terdapat 27 orang, 2012 terdapat 24 orang, 2013 terdapat 30 orang(5,17\%), dan Januari - Agustus 2014 tercatat 13 orang.

Tingginya angka kehamilan pada remaja atau kehamilan dini ini tentunya akan membawa dampak sosial maupun kesehatan. Banyak komplikasi yang dapat terjadi kepada ibu dan bayi sejalan dengan kehamilan dan proses persalinan. Menurut WHO, penyebab tertinggi kematian wanita usia 15-19 tahun di negara dengan penduduk yang memiliki pendapatan per kapita rendah atau sedang adalah komplikasi selama kehamilan dan persalinan. Kehamilan pada remaja putri juga erat hubungannya dengan induksi aborsi apabila kehamilan tersebut tidak diinginkan, dan sekitar 4 juta remaja tercatat setiap tahunnya melakukan aborsi, 67.000 diantaranya meninggal karena tindakan aborsi yang tidak aman. ${ }^{2,5,6,7}$
Banyak faktor yang dapat memicu terjadinya kehamilan dini. Salah satunya adalah, pengetahuan tentang kehamilan itu sendiri.Di mana tingkat pengetahuan seseorang akan mempengaruhi perilaku seksual pranikah.Hal lain yang mempengaruhi insiden kehamilan dini adalah pernikahan pada usia yang masih tergolong remaja. Indonesia duduk di ranking 37 seluruh dunia dan peringkat tertinggi kedua di ASEAN setelah Kamboja dalam jumlah pernikahan dini. Pengalaman seksual sebelumnya, dukungan keluarga, riwayat sosial dan pergaulan, dan pendidikan juga memberi sumbangsi dalam jumlah kehamilan dini. ${ }^{2,8,9}$

Pendidikan seks memang tidak secara resmi diberikan di sekolah sehingga konsekuensinya adalah pengetahuan mengenai seksualitas dan kesehatan reproduksi menjadi lebih terbatas. Hal ini mendorong remaja untuk lebih menggali informasi dari teman sebaya atau lingkungan sosial yang tidak memiliki dasar sumber informasi yang jelas dan terpercaya. Menurut Soetjiningsih, perilaku seks pranikah sangat dipengaruhi oleh tekanan negatif temanteman sebaya. Terkadang informasi yang didapatkan dari teman- teman memicu rasa ingin tahu dan penasaran remaja, sehingga berdampak pada perilaku seks pranikah. ${ }^{10}$

\section{METODE PENELITIAN}

Penelitian pada tanggal 7 Agustus - 6 September 2014 menggunakan rancangan penelitian deskriptif kualitatif untuk menggambarkan pengetahuanremaja putri dengan kehamilan di wilayah kerja Puskesmas Klungkung I.Penentuan sampel dilakukan secara non-random, purposive sampling. Sampel adalah remaja putri yang sedang hamil, dipilih sejumlah 6 orang responden yang telah menyetujui informed consent. Dengan bantuan kader desa, peneliti membuat janji temu- wicara dengan responden secara langsung secara individu. Dengan variabel pengetahuan responden dan subvariabel paparan informasi dan informasi mengenai pencegahan kehamilan dini.Wawancara 
direkam dengan alat perekam suara digital atas persetujuan responden untuk memastikan pengumpulan data yang lengkap dan akurat.

Data yang didapatkan adalah data primer dan isi wawancara dilakukan berdasarkan pedoman wawancara yang telah dipersiapkan sebelumnya. Data yang diperoleh dari hasil wawancara (pertanyaan dan jawaban wawancara) akan ditranskripsi oleh pewawancara yang melakukannya dan dilakukan secara verbatim, kata per kata, mencakup semua gaya bahasa informal dan ekspresi emosi selama wawancara. Selanjutnya data akan diberi kode (coding), dan dilakukan thematic analysis. Data hasil thematic analysis akan disajikan dalam bentuk deskripsi dalam laporan penelitian.

HASIL PENELITIAN

DAN PEMBAHASAN

Karakteristik Responden
Penelitian ini melibatkan enam orang remaja putri<20 tahun yang melakukan kontrol kehamilan antara tanggal 7 Agustus - 6 September 2014 di wilayah kerja Puskesmas Klungkung I sebagai responden dengan asumsi responden dapat memberikan gambaran mengenai pengetahuan terhadap kehamilan di usia dini. Berikut karakteristik responden penelitian (tabel 1): Inisial SU[R1], 17 tahun, pendidikan terakhir SD, status menikah dan tidak bekerja.Responden RA[R2], 17 tahun, tamat SMP, tidak menikah dan tidak bekerja. Responden LAK[R3], tamat SMP, status menikah dan tidak bekerja. Responden DSA[R4], 18 tahun, pendidikan terakhir 2 SMA, status menikah dan tidak bekerja. Responden KW[R5], 19 tahun, tamat SMP, status menikah dan tidak bekerja. Ini merupakan kehamilan pertama bagi kelima responden. Responden KA[R6] 19 tahun, tamat SMA, status menikah dan bekerja, ini adalah kehamilan ketiga.

Tabel 1. Karakteristik Responden

\begin{tabular}{|c|c|c|c|c|c|c|c|c|}
\hline No. & Inisial & $\begin{array}{l}\text { Umur } \\
\text { (tahun) }\end{array}$ & Asal & $\begin{array}{c}\text { Pendidikan } \\
\text { terakhir }\end{array}$ & $\begin{array}{c}\text { Status } \\
\text { pernikahan }\end{array}$ & $\begin{array}{c}\text { Status } \\
\text { pekerjaan }\end{array}$ & $\begin{array}{c}\text { Kehamilan } \\
\text { ke- }\end{array}$ & Ket \\
\hline 1. & SU & 17 & Karangasem & SD & Menikah & Tidak & 1 & R1 \\
\hline 2. & RA & 17 & Karangasem & SMP & Tidak & Tidak & 1 & $\mathbf{R} 2$ \\
\hline 3. & LAK & 18 & Karangasem & SMP & Menikah & Tidak & 1 & R3 \\
\hline 4. & DSA & 18 & Karangasem & $2 \mathrm{SMA}$ & Menikah & Tidak & 1 & R4 \\
\hline 5. & $\mathrm{KW}$ & 19 & Karangasem & SMP & Menikah & Tidak & 1 & R5 \\
\hline 6. & KA & 19 & $\begin{array}{c}\text { Nusa } \\
\text { Penida }\end{array}$ & SMA & Menikah & Bekerja & 3 & R6 \\
\hline
\end{tabular}

Untuk memahami dan meng-gambarkan pengetahuan remaja putri mengenaikehamilan di usia dini di wilayah kerja Puskesmas Klungkung I, peneliti melakukan in-depth interview terhadap enam orang remaja putri yang mengalami kehamilan selama tahun 2014 di wilayah tersebut dengan mengunjungi rumah responden satu per satu. Wawancara membahas bagaimana pengetahuan responden terhadap kehamilan di usia dini.

\section{Gambaran Pengetahuan Remaja Putri mengenai Kehamilan}

Pengetahuan sebagai apa yang telah diketahui seseorang melalui penginderaannya merupakan suatu hal yang dapat mempengaruhi bagaimana seorang individu dapat memutuskan suatu sikap dan perilaku. Hasil penelitian di Kupang, Palembang, Singkawang, Cirebon dan Tasikmalaya pada tahun 2001 yang disampaikan dalam 
kepustakaan Taufik pada tahun 2010 menemukan pengetahuan dasar responden tentang kesehatan reproduksi tidak memadai. Hasil penelitian oleh Taufik sendiri menunjukkan bahwa sebagian besar responden mengetahui tentang apa itu seks pra-nikah dan selebihnya menuturkan pada awalnya dulu ketika melakukan hubungan seks pra-nikah tidak terlalu mengetahui tentang apa itu seks pra-nikah dan hanya beranggapan untuk senang-senang dan mencari kenikmatan saja. ${ }^{11}$

Sesuai dengan penemuan tersebut, pada penelitian ditemukan hanya satu responden yang pernah diberikan edukasi seksual di sekolah, sedangkan responden lainnya me-ngaku hanya pernah diinformasikan oleh keluarga.

Gak ada sih. Cuma taunya kalau berhubungan bisa hamil..

Ga pernah, dulu pernah sih dapet pas IPA tapi ga ada dikasitau tentang itu. Dari keluarga pernah tapi kan di seksnya ga dibilangin. Cuma dibilangin jangan berhubungan seksual dulu sebelum menikah.

Pernah sih di sekolah..

Berdasarkan penelitian di SMAN 2 Magetan oleh Apriani pada tahun 2010, didapatkan hasil, semakin tinggi tingkat pengetahuan akan masalah reproduksi maka responden semakin tidak setuju dengan prilaku seksual pranikah.. Hal ini sesuai dengan hasil penelitian yang menunjukkan kecenderungan kurangnya pengetahuan responden mengenai masalah seksual. ${ }^{12}$

\section{Paparan Informasi}

Pada penelitian ini juga menemukan seluruh responden memiliki teman atau saudara yang memiliki ke-hamilan di usia muda.
Ada, sepupu saya. Umur 15 tahun udah nikah..

Ada sih, waktu saya kelas 2 SMP, temennya ada yang hamil.

Ada, teman sekelas.

Penemuan ini juga mendukung kesimpulan yang diberikan oleh Soetjiningsih dalam disertasinya, dimana dalam studi tersebut disebutkan semakin tinggi tekanan berperilaku negatif yang dilakukan oleh teman, terutama teman sebaya semakin tinggi pula perilaku seksual pra-nikah yang akan dilakukan. Bagaimana hal tersebut dapat mempengaruhi perilaku responden, namun berdasarkan pustaka, remaja cenderung mengadopsi informasi yang diterima oleh teman-temannya, tanpa memiliki dasar informasi yang signifikan dari sumber yang lebih dapat dipercaya. Informasi dari teman-temannya tersebut, dalam hal ini sehubungan dengan perilaku seks pra-nikah, menimbulkan rasa penasaran yang membentuk serangkaian pertanyaan sehingga untuk menjawab pertanyaan itu sekaligus membuktikan kebenaran informasi yang diterima, mereka cenderung melakukan dan mengalami perilaku seks pranikah itu sendiri. ${ }^{10}$ Pada jurnal ini akan ditelaah mengenai gambaran pengetahuan seorang remaja yang dapat mempengaruhi terjadi kehamilan dini. Pengetahuan (knowledge) menurut Bloom dalam Notoatmodjo, adalah hasil penginderaan manusia, atau hasil tahu seseorang terhadap objek melalui indera yang dimilikinya (mata, hidung, telinga dan sebagainya). Pengetahuan terkait kesehatan reproduksi adalah men-cakup apa yang diketahui oleh individu terhadap kesehatan reproduksi diantaranya: susunan dan fungsi sistem reproduksi, proses dan pencegahan/penanggulangan akan kehamilan, 
aborsi dan dampaknya, penyakit-penyakit kelamin. ${ }^{13}$

Survei LDFEUI(Lembaga Demografi Fakultas Ekonomi Universitas Indonesia) juga menemukan rendahnya pengetahuan responden mengenai seksualitas. ${ }^{11}$

\section{Informasi mengenai Pencegahan Kehamilan Dini}

Pendidikan seksual seringkali tidak secara resmi diberikan di sekolah dan sebagai konsekuensinya, pengetahu-an remaja tentang isu-isu seksualitas dan kesehatan reproduksi sangat terbatas. Hal ini didukung dengan anggapan-anggapan responden me-ngenai apa yang mereka ketahui mengenai berhubungan seksual dimana mereka hanya mengetahui berhubungan seksual bisa hamil, namun tidak mengetahui cara untuk mencegah kehamilan ataupun bagaimana dampak dari kehamilan di usia dini tersebut. Dengan bermodal kata-kata mau bertanggungjawab yang dikatakan oleh pasangan pria, lima orang responden bersedia untuk melakukan hubungan seksual pra-nikah.

Gatau. ya taunya kalo berhubungan bisa hamil, terus ya asal dia mau tanggung jawab ya terserah dia aja. Ga ngerti juga soal kontrasepsi..

Saya tau bisa hamil makanya dapat nanya pas berhubungan, kalau hamil gimana, terus dia bilang akan tanggung jawab. Terus yaudahlah kalau udah mau. Kalo soal kontrasepsi pernah denger tapi ga ngerti juga.

Belum pernah ada yang ngasi tau tentang dampak kehamilan dini.

Hal ini juga ditemukan rendahnya pengetahuan responden mengenai seksualitas pada penelitian lainnya dimana salah satu diantaranya adalah adanya anggapan dari 53,9\% responden pada survei LDFEUItahun 1999 menyatakan bahwa jika hanya sekali melakukan hubungan seksual maka tidak akan menyebabkan kehamilan. Keyakinan yang salah tersebut justru lebih banyak ditemukan pada responden perempuan daripada laki-laki. Pada penelitian oleh Taufik ditunjukkan sebagian besar informan mengetahui tentang apa itu seks pra-nikah namun selebihnya menuturkan pada awalnya ketika melakukan hubungan seks tersebut tidak terlalu mengetahui tentang apa itu seks pra-nikah dan hanya beranggapan untuk senang-senang dan mencari kenikmatan saja. Hasil penelitian oleh Arsih, Dariah dan Yuniarti et al juga menemukan bahwa remaja putri kurang mengetahui tentang kehamilan usia dini dan terdapat hubungan yang signifikan antara pengetahuan dengan sikap remaja putri tentang kehamilan usia dini. ${ }^{11}$

\section{KELEMAHAN PENELITIAN}

Pada penelitian ini didapatkan kurangnya paparan informasi akan menyebabkan pengetahuan responden mengenai kehamilan menjadi terbatas, hal ini mendorong terjadi perilaku seksual pra nikah, namun peneliti juga belum bisa menyingkirkan faktor- faktor lain yang kira nya mempengaruhi kejadian kehamilan dini.

\section{SIMPULAN}

Dari penelitian yang sudah dilakukan selama satu bulan di Puskesmas Klungkung I, peneliti dapat menyimpulkan sebagian besar remaja putri dengan kehamilan tidak mendapatkan informasi yang cukup maupun edukasi formalatau non- formal mengenai hubungan seksual dan kehamilan sehingga tidak mengetahui dampaknya. Adapun remaja mengetahui berhubungan seksual bisa menyebabkan hamil, namun tidak mengetahui cara untuk mencegah kehamilan. Remaja juga memiliki teman atau saudara yang memiliki kehamilan di usia muda yang berpengaruh pada perilaku seksual pra-nikah. 


\section{DAFTAR PUSTAKA}

1. Dhamayanti, Meita. Overview adolescent health problem and services. Adolescent Health National Symposia: Current Challenges in Management. Ed 2. IDAI: 2013.

2. UNFPA. Adolescent pregnancy: A review of the evidence. New York. 2013.

3. Riskesdas. Riset Kesehatan Dasar. Litbang Kemenkes RI.2013.

4. Widjanarko, Bambang. Ginekologi Anak dan Remaja. 2009. [diakses 7 Agustus 2014].Diunduh dari: URL: http://reproduksiumj.blogspot.com/2009 /11/ginekologi-anakdanremaja.html.

5. Surilena. Fenomena Seks Bebas pada Remaja di Indonesia. Kedokteran Damianus 2006 5(2): 83-107.

6. Indonesia Country Report. The Development of Adolescent Reproductive Health in Indonesia. Paper is Part of the Indonesia Country Report at The Fifth Asia Pasific Population Conference, Bangkok, Thailand. 2002.

7. WHO. Early marriages, adolescent and young pregnancies. World Health Organization A65/13. 2009.

8. Vollan, Teresa dan Caitlin Safford. 2014. Teen Pregnancy and Child Bearing. Washington State Department of Health.

9. Trisnayani, 2013. Profil Survei Remaja. Semarapura: UPT Kesmas Klungkung II

10. Pratiwi, Niniek L. dan Hari Basuki. Analisa perilaku seks pertama kali tidak aman pada 15-24 tahun dan kesehatan reproduksi. Bultn Peneltn Sist Kes2010 (13:4):309-320

11. Taufik, M. 2010. Analisis penyebab perilaku hubungan seksual pranikah pada remaja di kota Pontianak (Studi kualitatif). Universitas Indonesia: FKM UI.

12. Apriani, Arista. 2010. Hubungan antara pengetahuan tentang risiko kehamilan remaja di luar nikah dengan sikap terhadap hubungan seksual pranikah pada siswa SMAN 2 Magetan. Surakarta: Universitas Sebelas Maret

13. Notoadmojo, Soekidjo. 2005. Promosi Kesehatan Teori dan Aplikasi. Jakarta: Rineka Cipta 